\title{
International Data on Educational Attainment: Updates and Implications
}

\author{
Robert J. Barro and Jong-Wha Lee
}

CID Working Paper No. 42

April 2000

(C) Copyright 2000 Robert J. Barro and Jong-Wha Lee and the President and Fellows of Harvard College
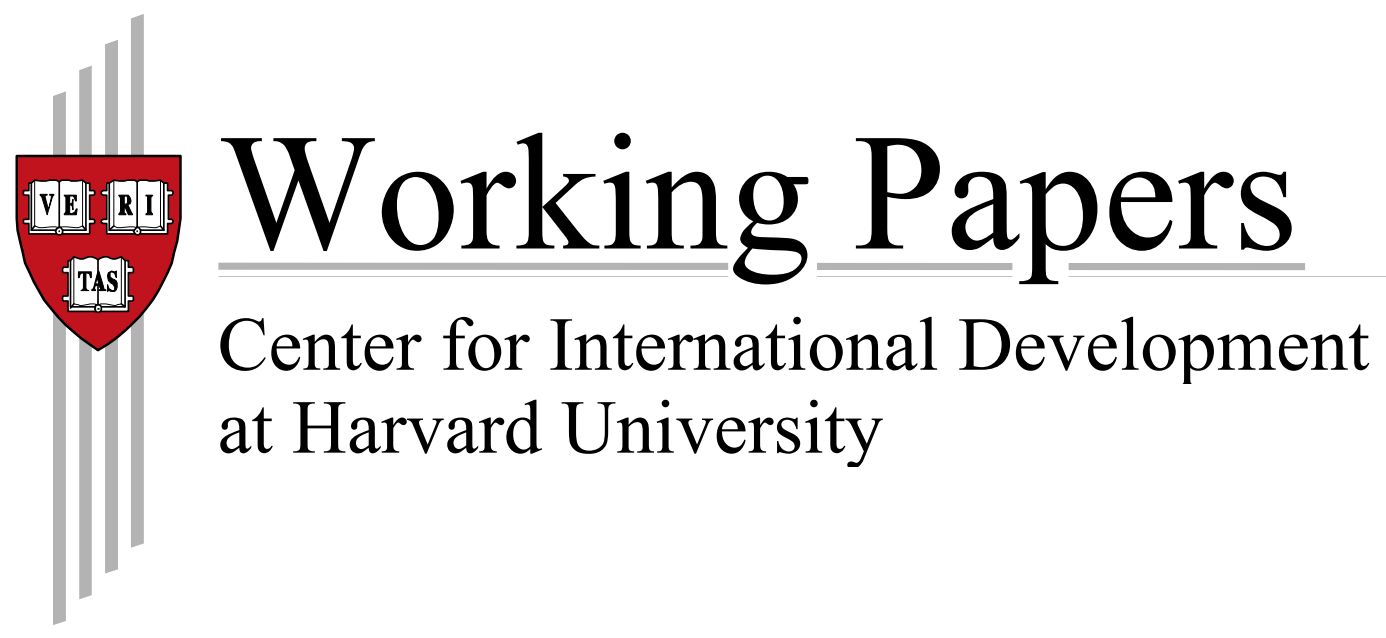


\title{
International Data on Educational Attainment: Updates and Implications
}

Robert J. Barro and Jong-Wha Lee

\begin{abstract}
This paper presents a data set that improves the measurement of educational attainment for a broad group of countries. We extend our previous estimates of educational attainment for the population over age 15 and over age 25 up to 1995 and provide projections for 2000 . We discuss the estimation method for the measures of educational attainment and relate our estimates to alternative international measures of human capital stocks.
\end{abstract}

Keywords: Education, Human Capital Formation

JEL Classification Codes: I20, J24
Robert J. Barro
Department of Economics
Harvard University
Littauer 120, Cambridge
MA02138USA
E-mail tbarro@harvard.edu

\author{
Jong-Wha Lee \\ Economics Department \\ Korea University \\ Anam-Dong, Sungbuk-Ku \\ Seoul 136-701, Korea \\ E-mail jongwha@kuccnx.korea.ac.kr
}

Originally presented at "Skill Measurement and Economic Analysis- An International Conference," University of Kent at Canterbury, England, March 27-29, 2000. This work was prepared while Jong-Wha Lee was a Visiting Fellow at the Center for International Development at Harvard University. 


\title{
International Data on Educational Attainment: Updates and Implications
}

\author{
Robert J. Barro and Jong-Wha Lee
}

\section{Introduction}

Human capital, particularly that attained through education, has been emphasized as a critical determinant of economic progress. A greater amount of educational attainment indicates more skilled and more productive workers, who in turn increase an economy's output of goods and services. An abundance of well-educated human resources also helps to facilitate the absorption of advanced technology from developed countries. In addition, the level and distribution of educational attainment has a strong impact on social outcomes, such as child mortality, fertility, education of children, and income distribution.

In order to quantify the relationship between educational attainment and economic and social outcome variables, there have been a number of attempts to measure educational attainment across countries. Earlier empirical studies used school enrollment ratios or literacy rates. These data are widely available but do not adequately measure the aggregate stock of human capital available contemporaneously as an input to production.

Our earlier study filled this gap in data by measuring educational attainment for a broad group of countries. ${ }^{1}$ The figures were constructed at five-year intervals from 1960 to 1985 (Barro and Lee, 1993). The data showed the distribution of educational attainment of the adult population aged 25 and over by sex at seven levels of schooling. In our subsequent work (Barro and Lee, 1996), we provided an update on the data for the population aged 25 and over up to

\footnotetext{
${ }^{1}$ Earlier attempts to construct measure of educational attainment for international comparisons include Psacharopoulos and Ariagada (1986), Lau et al. (1991), and Nehru et al. (1995). Their measures were hampered by more limited coverage of data and by potentially larger measurement errors than ours (see the discussion in footnote 1 of Barro and Lee (1996)).
} 
1990 and also constructed estimates of attainment for the population aged 15 and over. The over-15 age group corresponds better to the labor force for many developing countries.

In this paper, we provide a further update of educational attainment up to1995 and also construct projections to 2000 . This data set improves on our earlier estimates in a number of respects. First, our fill-in procedure for missing census/survey observations now uses gross enrollment rates, adjusted for repeaters. This measure reflects the inflows of new school graduates to existing educational stocks more accurately than the usual gross or net enrollment ratios. Second, in the construction of average years of schooling, we now take account of changes of school duration over time within countries.

Our data set on educational attainment provides good measures of the human capital stock for a broad number of countries. ${ }^{\mathrm{Q}}$ The data set comprises at least one observation for 142 economies, of which 109 have complete information at five-year intervals from 1960 to 2000. The percentage of the population who have successfully completed a given level of schoolingsay secondary, tertiary, or post-primary schooling —is a straightforward way to show the population's attainment of skills and knowledge associated with a particular level of education. In practice, however, each cycle of education has significant variation in duration across countries. We take account of this variation by using information on the typical duration of each level of schooling within countries. With these data we can also construct measures of average years of schooling at all levels for each country.

\footnotetext{
${ }^{2}$ Our estimates of educational attainment have been used in many previous studies. Empirical work that uses our data set includes Rajan and Zingales (1998) and Ramey and Ramey (1995) in American Economic Review; Barro (1999) in Journal of Political Economy; Easterly and Levine (1998) and Hall and Jones (1999) in Quarterly Journal of Economics; and Sachs and Warner (1995) in Brookings Papers on Economic Activity. Up to February 2000, our papers on educational attainment data (Barro and Lee,1993 and 1996) have been cited at least 90 times, according to the Social Science Citations Index.
} 
Because human capital is multifaceted and includes a complex set of human attributes, the stock of human capital held by individuals is hard to measure with precision in a quantitative form. Educational attainment is at best a proxy for the component of the human capital stock obtained at schools. In section IV, we relate our measure of educational attainment to alternative measures of human capital, such as international test scores, results from the international adult literacy survey, and estimates of labor-market outcomes. We also compare our numbers to the OECD's recent estimates of educational attainment.

\section{The Estimation of Educational Attainment}

This section summarizes the main procedure for constructing the estimates of human capital stock and discusses the modifications that have been made in the present update.

\section{Estimation Method}

The estimation procedure is a perpetual inventory method, using the census/survey observations on attainment as benchmark stocks and new school entrants as flows that are added to the stocks with an appropriate time lag.

The benchmark figures on school attainment have been collected, as before, from census/survey information, as compiled by UNESCO and other sources. The census/survey figures report the distribution of educational attainment in the population stratified by age and by sex in, for most cases, six categories: no formal education, incomplete primary, complete primary, first cycle of secondary, secondary cycle of secondary, and tertiary. ${ }^{\text {The present data }}$

\footnotetext{
${ }^{3}$ The classification of levels of education is based on the common criterion for international comparison that was adopted in 1976 as the International Standard Classification of Education (ISCED, 1976). Countries may not always classify diplomas and qualifications at the same ISCED levels, so the UNESCO classification may differ from the national classification.
} 
set adds more census information for 1990 and 1995 and updates the estimates of educational attainment to 2000. This data set also includes new observations for the transitional economies that became independent in the 1990s.

Tables 1 and 2 summarize the coverage of the census data for two groups of the total population - aged 15 and over and aged 25 and over. Table 1 shows the distribution of countries by the number of census/survey observations available since 1950. For persons aged 15 and over, 141 countries have at least 1 observation, and 72 countries have 3 or more observations. Table 2 shows the distribution of numbers of observations by census-survey year since 1950 (where the underlying figures are applied to the nearest 5-year value). For the population over age 15, 59 observations are available for 1960, 62 for 1970, 75 for 1980, and 56 for 1990. The total number of observations is 379, of which 354 are between 1960 and 1995 . These 354 data points are used for the benchmark figures on educational attainment.

We fill in most of the missing observations on school attainment by using information on school-enrollment ratios and the structure of population by age groups. Following the perpetual inventory method, we construct current flows of adult population that are added to the benchmark stocks. The formulas for the various levels of schooling for the population aged 15 and over are as follows. 4
(1) $H_{0 . t}=H_{0, t-5}\left(1-\delta_{t}\right)+L 15_{t} *\left(1-P R I_{t-5}\right)$
(2) $H_{1, t}=H_{1, t-5}\left(1-\delta_{t}\right)+L 15_{t} *\left(P R I_{t-5}-S E C_{t}\right)$
(3) $H_{2 . t}=H_{2, t-5}\left(1-\delta_{t}\right)+L 15_{t} * S E C_{t}-L 20_{t} * H I G H_{t}$

\footnotetext{
${ }^{4}$ For the procedure applied to the population aged 25 and over, see Barro and Lee (1993, part II).
} 
(4) $H_{3, t}=H_{3, t-5}\left(1-\delta_{t}\right)+L 20_{t} * H I G H_{t}$

where $\mathrm{H}_{\mathrm{jt}}$ is the number of persons aged 15 and over for whom $\mathrm{j}$ is the highest level of schooling attained; $\mathrm{j}=0$ for no school, 1 for primary, 2 for secondary, and 3 for higher. L15 denotes the number of persons aged 15-19 and L20 denotes the number of persons aged 20-24. The variables PRI, SEC, and HIGH are the enrollment ratios for primary, secondary, and higher schools, respectively. The enrollment ratios are the gross ratios adjusted for school repeaters, as we will explain in the next section. The assumption in equations (1)-(4) is that persons aged 1519 would have received primary schooling 5 years earlier (if they were enrolled) and would receive secondary education contemporaneously. Persons aged 20-24 would receive higher schooling contemporaneously. The variable $*_{\mathrm{t}}$ is the mortality rate for persons aged 15 and over and is estimated from

$$
\text { (5) } \delta_{t}=\left(L 15_{t}+L_{t-5}-L_{t}\right) / L_{t-5} \text {, }
$$

where $L_{t}$ is the total population aged 15 and over. The assumption in equations (1)-(4), which is not entirely accurate, is that the mortality rate is independent of the level of schooling attained.

Substitution from equation (5) into equations (1)-(4) yields the formulas that we use to fill in the cells for the attainment ratios, $\mathrm{h}_{\mathrm{jt}}=\mathrm{H}_{\mathrm{jt}} / \mathrm{L}_{\mathrm{t}}$ :

$$
\begin{aligned}
& \text { (6) } h_{0, t} \equiv H_{0 . t} / L_{t}=h_{0, t-5}\left[1-\left(L 15_{t} / L_{t}\right)\right]+\left(L 15_{t} / L_{t}\right) *\left(1-P R I_{t-5}\right) \\
& \text { (7) } h_{1, t} \equiv H_{1 . t} / L_{t}=h_{1, t-5}\left[1-\left(L 15_{t} / L_{t}\right)\right]+\left(L 15_{t} / L_{t}\right) *\left(P R I_{t-5}-S E C_{t}\right) \\
& \text { (8) } h_{2, t} \equiv H_{2 . t} / L_{t}=h_{2, t-5}\left[1-\left(L 15_{t} / L_{t}\right)\right]+\left(L 15_{t} / L_{t}\right) * S E C_{t}-\left(L 20_{t} / L_{t}\right) * H I G H_{t} \\
& \text { (9) } h_{3, t} \equiv H_{3, t} / L_{t}=h_{3, t-5}\left[1-\left(L 15_{t} / L_{t}\right)\right]+\left(L 20_{t} / L_{t}\right) * H I G H_{t}
\end{aligned}
$$


The application of equations (6)-(9) generates our panel data set on educational attainment for the population aged 15 and over from 1960 to 2000 at the four broad levels of schooling: no school, some primary, some secondary, and some higher. We then break down the three levels of schooling into incomplete and complete education by using estimates of completion ratios.

We use the same sources and methodology to construct a panel data set on the educational attainment of females over age 15 and over age 25 at five-year intervals from 1960 to 2000 .

The data on the distribution of educational attainment among the population, combined with the information for each country on the duration of school at each level, generate the number of years of schooling achieved by the average person at the various levels and at all levels of schooling combined.

\section{Modifications}

The present estimates and projections improve on earlier data by making a few modifications in the fill-in procedure of missing observations and in the construction of average years of schooling.

Adjusted gross enrollment ratios for the fill-in procedure

Our procedure for filling in missing observations requires school enrollment rates. In the first version of the data set (Barro and Lee, 1993), we used the gross enrollment ratio, which is

\footnotetext{
${ }^{5}$ The completion ratios for the age 25 and over population group are described in Barro and Lee (1993, Tables 4, 5, and 7). The completion ratios for the age 15 and over group are reconstructed from those for the age 25 and over group. The adjustment is that secondary-school enrollees aged 15-20 are treated
} 
defined as the ratio of all persons enrolled at a given level of schooling to the population of the age group that national regulation or custom dictates should be enrolled at that level. For example, the total registered students in primary school are typically compared with the population aged 6-11 years. However, the gross ratios will overstate the accumulation of human capital when students repeat grades.

In the next revision (Barro and Lee, 1996), we used the net enrollment ratio, which is defined as the ratio of students at a given level of schooling in the designated age group to the total population of that age group. For example, the registered students aged 6-11 years in primary school are compared with the total population aged 6-11 years. Accordingly, this concept does not count students in primary school who are younger than 6 or older than 11 .

Net enrollment ratios also introduce measurement error if there are under- or over-aged children starting each level of education. If a proportion of the population enrolls at a given level at an age consistently earlier or later than that prescribed by regulation and consequently finishes school earlier or later, then net enrollment ratios understate the accumulation of schooling capital. Students who start school early or late constitute a significant fraction of total enrollments in many countries. For instance, for 12 Sub-Saharan African countries, a large fraction - between 10 and 33\%--of enrollment in grade 1 of primary education is made up of students younger than the official entrance age. In 31 countries, at least $50 \%$ of the students enrolled in grade 1 of primary school are older than the prescribed entry age (Gajraj, 1992). Although the over-aged students enrolled in this grade are due in part to repetition, the incidence of a high proportion of over-aged students in countries where the proportion of repeaters is small demonstrates the importance of late entry.

as incompletely educated at the secondary level, and higher-school enrollees aged 20-24 are treated as incompletely educated at the higher level. 
In response to this problem, we have revised our fill-in procedure to use 'adjusted gross enrollment ratios,' instead of the usual gross or net ratios, for primary and secondary schools. (We use the gross ratios for tertiary schools.) We construct the new ratios by adjusting the gross enrollment ratios for repetition rates. ${ }^{[}$

\section{Changes in the duration of years of schooling}

In the previous data set, we provided average years of schooling — at each level and at all levels of schooling combined - as an aggregate measure of the educational stock. To construct the average years of schooling, we used each country's typical duration of years of schooling at each level. For example, we assumed that the population who completed primary school obtained the country's full duration of primary schooling (Barro and Lee, 1993, p.387). However, since our procedure used each country's duration data for 1965, we did not take account of changes over time in a country's typical duration of schooling at each level. This approach creates measurement error, because a significant number of countries have altered the durations of their school systems. Over the last three decades, 32 countries have changed at least once the typical duration of schooling at the primary or secondary levels (see UNESCO, Statistical Yearbook, various years).

In the present revision, we take account of changes in the duration of schooling within countries. These changes would take time to become effective because the pupils who have received education in the new system will be new entrants into the adult population with a long time lag. We assume that changes in the duration of schooling at primary level apply to new

\footnotetext{
${ }^{6}$ See Lee and Barro (1997) for a discussion of the repetition data. Although a proper accounting of the net inflows to the human capital stock would also deduct dropouts from gross enrollments, the effect from dropouts is already taken into account by our measures of incomplete attainment at primary and secondary schools.
} 
entrants into the population over age 15 in 10 years and into the population over age 25 in 20 years, while the changes at secondary level become effective for the population over age 15 in 5 years and for the population over age 25 in 15 years,.

\section{The Complete Data Set on Educational Attainment, 1960-2000}

Appendix Tables A.1- A.2 contain the full data set on attainment at the seven levels of schooling for the overall population over age 25 and over age 15. Appendix Tables A.3- A.4 report the same estimates for the female population. The tables also report the average number of years of schooling achieved by the average person in each country. ${ }^{\text {] }}$

Table 3 summarizes the schooling data by region from 1960 to 2000 for 109 countries that have complete information. The table considers groups of 23 advanced countries, 13 transitional economies (TEs), and 73 developing countries. The developing group is further broken down into five regions: Middle East/North Africa (11 countries), Sub-Saharan Africa (22), Latin America/Caribbean (23), East Asia/Pacific (10), and South Asia (7). Regional averages are computed by weighting each country's observation by its share of the regional population aged 25 and over.

Table 3 shows that educational progress has continued in most regions except the transitional economies in the 1990s. For the 23 advanced countries, the average years of schooling for persons aged 25 and over increased from 9.3 years in 1990 to 9.8 years in 2000. For the 73 developing countries, the average years of attainment grew by $23 \%$ from 4.0 years in 1990 to 4.9 years in 2000 . In the 13 TEs, the average years of schooling remained at the same

\footnotetext{
${ }^{7}$ The Appendix Tables and the complete panel data set including the average number of years of schooling at the various levels will be available from the web site of the Center for International Development at Harvard University (http://www.ksg.harvard.edu/CID).
} 
level of 10.0 years in the 1990s. Among the developing regions, Sub-Saharan Africa and Middle East/North Africa showed the strongest progress, growing by about $35 \%$ in the 1990 s from 2.8 to 3.8 years and from 3.8 to 5.1 years, respectively.

Although the educational progress of the developing region as a whole has been relatively strong over the last decade, the education level in this region still lags far behind the advanced and TE regions. For the developing countries in 2000,37\% of the population aged 25 and over still had no formal schooling and only $27 \%$ had some secondary education. For the advanced and transition countries groups, in contrast, about two-thirds of the population over age 25 had at least some secondary schooling.

Table 4 presents the time-series data on educational attainment by group for the population aged 15 and over. The regional patterns are similar to those for the population aged 25 and over. For most regions, the average years of schooling for the aged 15 and over population group are slightly higher than those for the aged 25 and over group. For the developing countries as a whole in 2000 , the population aged 15 and over is projected to have an average school attainment of 5.1 years, compared to 4.9 years for the population aged 25 and over.

We have also constructed the data on educational attainment for the female population over age 25 and over age 15 . Table 5 uses these results and compares the regional figures for females with those for males for the period from 1960 to 2000 by region. The table shows the "gender ratio," defined as the ratio of female to male attainment (expressed as a percentage). In all regions, there has been a substantial rise in gender equality over the last decade. In the developing countries as a whole, the ratio rose from $63 \%$ in 1990 to $70 \%$ in 2000 for the population aged 25 and over, and from $69 \%$ in 1990 to $73 \%$ in 2000 for the population aged 15 
and over. During this period, the ratios rose notably in Middle East/North Africa (57\% to 68\% for the population over age 25 ) and South Asia ( $44 \%$ to $53 \%$ for the same age group). Note, however, that the gender gap in education is still large in these regions, compared to those in the advanced, TEs, and Latin American regions, where the ratios are typically well over 90\%. 


\section{Comparisons with Alternative Measures of the Human Capital Stock}

Our estimates of educational attainment provide a reasonable proxy for the stock of schooling capital for a broad group of countries. However, these data have a number of shortcomings. First, the measure of educational attainment does not take account of the skills and experience gained by individuals after their formal education. Second, the measure does not directly measure the human skills obtained at schools and, specifically, does not take account of differences in the quality of schooling across countries. In this section, we compare our concept of educational attainment with alternative measures of the stock of human capital.

\section{International Test Scores by Students}

An alternative measure of educational stock, which is considered to reflect variations of educational quality across country, is scores on internationally comparable tests of educational achievement. Conceptually, the quality of education is reflected in the performance of students and graduates. One indicator of schooling quality is students' scores on internationally comparable tests. Hanushek and Kim (1995) constructed a cross-section data set of international test scores in the subjects of science and mathematics for 39 countries. Lee and Barro (1997) have compiled test scores on the examinations in science, mathematics, and reading that have been conducted in various years for up to 58 countries by the International Association for the Evaluation of Educational Achievement (IEA) and the International Assessment of Educational Progress (IAEP). These studies cover primary or secondary students of the same age or grade group, such as age 9, age 13, and pupils in the last year of secondary education. Since the tests are carefully designed to ensure international comparability, the test scores would capture the 
cross-country variations in cognitive skills of the students and thereby measure differences in the quality of the future labor force. Hanushek and Kim (1995) and Barro (2000) find that test scores are positively related to growth rates of real per capita GDP in cross-country regressions. One shortcoming of these data, however, is that the observations apply to different years and are most abundant for the 1990s. The sample sizes are also much smaller than those for average years of schooling.

Table 6 shows the average test scores on mathematics and science for the students at the seventh grade for 39 countries that participated in the Third International Mathematics and Science Study (TIMSS) in 1994 and 1995. The scores are expressed on proficiency scales (scales ranging from 0 to 1000 , with a mean of 500 and a standard deviation of 100). Among the 39 participating countries, students in the four East Asian economies, Singapore, Korea, Japan, and Hong Kong, showed the highest achievement in the mathematics. Their average scores, ranging from 564 (Hong Kong) to 601 (Singapore) are well above the international average of 484. In contrast, South Africa and Colombia performed significantly less well than the other countries, with means below 400. The pattern of the country performances is similar for science achievement. The correlation between the two test scores is 0.85 .

The correlation between these students' test scores and average years of schooling is not very high. The correlation of average years of schooling in 1995 with the mathematics or science test score is 0.38 . The statistical significance of a test-scores variable in cross-country growth regressions, even when the average years of schooling are held constant, indicates that the test scores provide useful information about a country's quality of education.

\section{International Adult Literacy Test}


Although the test scores of students reflect the quality of schooling and, hence, indicate the quality of the labor force, they do not directly measure the educational capital held by a country's working-age population. Knowledge can be gained or lost after the completion of formal education. Ideally, tests of cognitive ability would be administered to adults, as well as to students. Recently, the International Adult Literacy Survey (IALS) has, for the first time, provided a direct comparison of certain work-related skills in the adult populations of various countries.

Although literacy was previously treated as a dichotomous concept—either literate or not - the OECD study considered the multifaceted nature of literacy and made efforts to measure

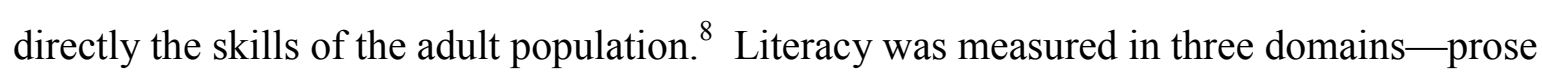
literacy, document literacy, and quantitative literacy. The literacy skills were evaluated in each country through detailed interviews with a sample of 2,000 and 8,000 persons in the working-age population. Results were reported on a scale from 0 to 500 in each of the three domains.

The IALS study is still in early stages and covers only 12 OECD countries. Seven countries participated in the first Survey—Canada, Germany, the Netherlands, Poland, Sweden, Switzerland (French-speaking and German-speaking, separately), and the United States. Five additional countries participated later-Australia, Belgium (Flanders), Ireland, New Zealand, and the United Kingdom (see OECD and Statistics Canada, 1995, and OECD and Human Resources Development Canada, 1998).

\footnotetext{
${ }^{8}$ The IALS defines "literacy" in terms of particular skills of adults "using printed and written information to function in society, to achieve one's goals, and to develop one's knowledge and potential" (OECD and Statistics Canada, 1995, p.3).

${ }^{9}$ For analytical purposes, the scores were also reported by five levels of literacy: Level 1 (0 to 225 points) indicates persons with very poor literacy skills, while Levels 4-5 (326-500 points) indicate that persons have the capacity to use higher-order thinking and information-processing skills.
} 
Table 6 shows the mean scores in each of the three domains for the 12 OECD countries. Sweden was the best performer in all domains, while Poland was the worst in all domains. The scores among the three domains are highly correlated, with correlation coefficients over 0.93 .

One surprising observation is the significant discrepancy in achievement between students and adults. Figure 1 depicts the TIMMS mathematics score and the IALS quantitative literacy score. The correlation between the two scores is only 0.07 in the common sample of 11 countries. In the scatter plot, however, Sweden seems to show an exceptionally large gap between the two test scores. The Swedish adults were the best performers in the quantitative literacy test, but the seventh-grade students showed very poor performance in the mathematics test in 1995.

Studies based on the IALS data show that these measures of literacy have a significant relation with gross earnings of individuals within a country, independently from the effects of education (OECD and Human Resources Development Canada, 1998).

\section{Estimates of the Market Value of Human Capital}

Another approach to measuring the stock of human capital is to assess differences in labor-market outcomes, such as earnings or employment of educated workers, that are attributable to the individuals' schooling. Along this line, there have been attempts to measure the human capital stock in terms of its market value. A labor-income-based measure is derived by weighting different segments of the workforce by the ratio of earnings at different levels of education. Gollop and Jorgenson (1980); Jorgenson, Gollop, and Fraumeni (1987); and

\footnotetext{
${ }^{10}$ The Swedish students at age 13 also showed below-average achievement in the Second International Mathematics Study that was conducted for 20 countries in 1982 . In contrast, in the same test, the $12^{\text {th }}$ grade students did very well, with the average score only lower than that of Finland among the OECD countries. This fact suggests that students attain significant quantitative skills at the secondary level.
} 
Mulligan and Sala-I-Martin (1995) used this method to estimate the human-capital stock of the United States. This measure, however, is not widely applicable to international comparisons due to the limited availability of detailed wage data for most countries.

A related issue is whether estimated rates of return, rather than durations of school, should be used as weights in the construction of aggregate human capital. Collins and Bosworth (1996) and Pritchett (1996) employed this method to construct measures of aggregate

educational attainment. Since the estimated rates of return measure productivity of education at each level, this measure is conceptually better than average years of schooling. A measure of average years of schooling assumes unrealistically that a year of education adds a constant quantity of human capital, whether undertaken by a primary pupil or a college student. One problem with the measure aggregated by rates of return, however, is that the available estimates of returns to schooling are not always accurate. For instance, the estimates may over-state returns because of the likely positive correlation between schooling and unmeasured characteristics such as ability. The significant variations in the available estimates for an individual country show that the estimates of returns are very sensitive to assumptions about social benefits, forgone earnings of students, and so on.

\section{OECD Estimates of Educational Attainment}

The OECD has also compiled data on educational attainment of the population in the 1990s. Most data come from labor-force survey based on small samples of households or individuals, in contrast to the national censuses in the UNESCO database (see OECD, 1998b, pp.377-79). For the years around 1995, the OECD data set covers 32 countries-24 OECD countries and 8 non-OECD countries. 
This data set presents the percentages of the population or labor force aged between 25 and 64 for whom the highest completed level of education falls into four categories: below upper-secondary education, upper-secondary education, non-university tertiary education, and university-level education. 1 One advantage of these estimates is that the population group covered corresponds closely to the labor force in the typical OECD country. However, the age group is less appropriate for developing countries, in which a substantial fraction of persons aged between 15 and 24 are in the workforce.

The OECD estimates of educational attainment correspond well to our numbers. Table 7 compares the two measures in terms of the percentage of the adult population aged 25 to 64 for the OECD and aged 25 and over in our measure by the level of schooling. We find the first OECD category- below upper secondary, would correspond roughly to the sum of our first three categories- no schooling, primary schooling, and partial secondary. In the common sample of 31 countries, the correlation between the two estimates is 0.78 . The OECD estimates of the population attaining upper secondary or higher education are also highly correlated with our measure of average years of schooling. The correlation is 0.87 .

Nonetheless, there are significant differences between the OECD and our data for some countries. For several countries, the OECD estimates show that the adult population had much higher attainment at upper-secondary and above than our estimates. For example, the OECD estimate shows about $84 \%$ of adult population in Germany attained education at the uppersecondary or tertiary level in 1995, while our estimate indicates the corresponding number is only $48 \%$. The discrepancy derives, in many cases, from the different classification between the OECD and the UNESCO sources. There is disagreement between international organizations

\footnotetext{
${ }^{11}$ The OECD publication also provides estimates for educational attainment of the population by sex and by disaggregated age groups, 25-34, 35-44, 45-54, and 55-64.
} 
about the allocation of different education and training to the categories of the international standard classification (Steedman, 1999). Although the ISCED provides guidance on which qualifications and stages of education should be assigned to the ISCED categories, the ISCED classifications do not fully reflect the heterogeneity of education system, in particular of vocational and non-academic educational training, across countries. In addition, when conflicting interpretations are possible, national governments can divide or reallocate qualification categories for the political considerations. Steedman (2000) points out that the UK chooses a definition of the ISCED levels which gives the impression that the education system produces a large supply of skills. Another source of the discrepancy is that our data refer to the population aged 25 and above, but the OECD data are for the population of age between 25 and 64. Since the population aged 65 and above have in general lower attainment than the younger population group, this difference would tend to make the OECD figures on upper secondary or tertiary attainment higher than our corresponding numbers. Further investigations on the exact relationship between our estimates and the OECD data on educational attainment are still in progress.

\section{Conclusion}

This paper presents a data set on educational attainment for the population over age 15 and over age 25 at five-year intervals between 1960 and 2000 for a broad number of countries. The data provide the distribution of educational attainment of the population at seven levels of schooling and show a breakdown by sex.

\footnotetext{
${ }^{12}$ Since the OECD and the UNESCO sources use different population groups and different school classifications, we have not utilized the OECD database for the estimation of our measure of educational
} 
This improved data set on educational attainment will continue to contribute to empirical research in many areas. Our data have been widely used to investigate the effects on economic growth of educational attainment, measured by overall years of schooling as well as by the composition of attainment at various levels of education. The data set has also been useful for studying the linkages across countries between education and other important economic and social variables, such as export competitiveness, fertility, income inequality, and political freedom.

There has been considerably more work in improving international measures of human capital. International test scores of students at the primary and secondary levels provide useful information on the quality of education. The International Adult Literacy Survey is a very promising attempt to measure directly the skills of the workforce for international comparison. However, these measures are at present restricted by the limited sample, which consists mostly of OECD countries. For future use, international efforts to extend the coverage of the IALS to more developing countries will be important. This extension would make it possible to assess the interactions between the quantity and quality of education for a broad panel of countries. It would also be possible to study further the effects of human capital on economic performance and to see how these effects interact with the level of economic development. 


\section{References}

Barro R.J., (1999)"Determinants of Democracy," Journal of Political Economy 107, Suppl., December, S158-S183.

Barro, R.J. (2000), "Education and Economic Growth," mimeo, Harvard University.

Barro, R.J. and J.W. Lee (1993), "International Comparisons of Educational Attainment," Journal of Monetary Economics, 32: 363-94.

Barro, R.J. and J.W. Lee (1996), "International Measures of Schooling Years and Schooling Quality," American Economic Review, 86(2), May: 218-223.

Collins, S. and B. Bosworth (1996), "Economic Growth in East Asia: Accumulation versus Assimilation," Brookings Papers on Economic Activity 2: 135-203.

Easterly, W, and Levine, R, (1998), "Africa's Growth Tragedy: Policies and Ethnic Divisions," Quarterly Journal of Economics 112, November, 1203-1250.

Gajraj, Suren (1992), "Primary Education- Age in Grade 1," Division of Statistics, UNESCO, November.

Gollop, Frank M. and Dale W; Jorgenson (1980), "U.S. Productivity Growth by Industry, 19471973, in New Developments in Productivity Measurement," edited by J. Kendrick and B. Vaccara, The University of Chicago Press, 117-136.

Jorgenson, Dale W., Frank M. Gollop and Barbara M. Fraumeni (1987), Productivity and U.S. Economic Growth, Cambridge, Harvard University Press.

Hall, R.E, and Jones, C.I, (1999), "Why Do Some Countries Produce So Much More Output Per Worker Than Others?", Quarterly Journal of Economics 114, February, 83-116.

Hanushek, Eric, and Dongwook Kim (1995), "Schooling, Labor Force Quality, and Economic Growth," Rochester Center for Economic Research, working paper no. 411, September.

Lau, L, D. Jamison, and F. Louat (1991), "Education and Productivity in Developing Countries: an Aggregate Production Function Approach," Report no. WPS 612, The World Bank, March.

Lee, J.W. and R. J. Barro (1997), "Schooling Quality in a Cross-section of Countries," NBER Working Paper 6198, September.

Mulligan, Casey B. and Xavier Sala-I-Martin (1995), "A Labor-Income Based Measure of the Value of Human Capital: An Application to the States of the United States," NBER Working Paper No. 5018. 
Nehru, V., E. Swanson, and A. Dubey (1995), "A New Data Base on Human Capital Stock: Sources, Methodology, and Results," Journal of Development Economics, 46(April), 379-401.

OECD (1998a), Human Capital Investment: An International Comparison, Centre for Educational Research and Innovation,

OECD (1998b), Education At A Glance: OECD Indicators, Centre for Educational Research and Innovation,

OECD and Statistics Canada (1995), Literacy, Economy and Society-Results of the First International Adult Literacy Survey, Paris and Ottawa.

OECD and Human Resources Development Canada (1998), Literacy Skills for the Knowledge Society: Further Results from the International Adult Literacy Survey, Paris and Ottawa.

Pritchett, L. (1996), "Where Has All the Education Gone?" World Bank Working Paper No. 1581.

Psacharopoulos, G. and A.M. Ariagada (1986), "The Educational Composition of the Labor Force: an International Comparison," International Labor Review, 125(September/October), 561-74.

Rajan, RG and Zingales, L, (1998), "Financial Dependence and Growth," American Economic Review 88, June, 559-586.

Ramey, G, and Ramey, VA, (1995)"Cross-country Evidence on the Link Between Volatility and Growth," American Economic Review 85, December, 1138-1151.

Sachs, J.D., and Warner, A, (1995) "Economic Reform and The Process of Global Integration," Brookings Papers on Economic Activity, 1-95.

Steedman, H. (1999) "Measuring the Quality of Educational Outputs: Some Unresolved Problems," forthcoming in Alexander R., Broadfoot P, and Phillips D. Learning from Comparing: New Directions in Comparative Education Research, Triangle Books, 1999.

Steedman, H. (2000) "Looking Into the Qualifications 'Black Box': What Can International Surveys Tell Us About Basic Competence?" Mimeo., Centre For Economic Performance, London School of Economics and Political Science.

UNESCO, Statistical Yearbook, various years, Paris. 
Table 1

Breakdown of Number of Countries

By Number of Census-Survey Observations

Number of Observations

(1950-1995)

\author{
Number of Countries \\ Population Population \\ aged $25 \&$ over aged $15 \&$ over
}

$31 \quad 35$

$34 \quad 34$

$25 \quad 35$

$33 \quad 24$

128

$6-3 \quad 2$

$7 \quad 3 \quad 2$

800

$9-11$

$\begin{array}{lll}\text { Total } & 142 & 141\end{array}$

Note: The data refer to census-survey observations for educational attainment for the total and female populations in each age category. 
Table 2

Breakdown of Number of Countries

By Number of Census-Survey Year

$\begin{array}{ccc}\begin{array}{c}\text { Census-survey year } \\ \text { (to the nearest 5-year value) }\end{array} & \begin{array}{c}\text { Number of Countries } \\ \text { Population } \\ \text { aged 25\& over aged 15\& over }\end{array} & \begin{array}{c}\text { Population } \\ 1950\end{array} \\ 1955 & 25 & 16 \\ 1960 & 14 & 9 \\ 1965 & 58 & 59 \\ 1970 & 28 & 24 \\ 1975 & 73 & 62 \\ 1980 & 42 & 43 \\ 1985 & 76 & 75 \\ 1990 & 23 & 24 \\ 1995 & 61 & 56 \\ & 14 & 11 \\ \text { Total } & & 379 \\ \text { Total 1960-95 } & 414 & 354\end{array}$

Note: The data refer to census-survey observations for educational attainment for the total and female populations in each age category. 
Table 3

Trends of Educational Attainment of the Total Population Aged 25 and Over by Region

\begin{tabular}{|c|c|c|c|c|c|c|c|c|c|c|}
\hline \multirow{3}{*}{$\begin{array}{c}\text { Region } \\
\text { (no. of } \\
\text { countries) }\end{array}$} & \multirow{3}{*}{ Year } & \multirow{3}{*}{$\begin{array}{l}\text { Pop. } \\
\text { over } 25 \\
\text { (mill.) }\end{array}$} & \multicolumn{7}{|c|}{$\underline{\text { Highest level attained }}$} & \multirow{3}{*}{$\begin{array}{l}\text { Average } \\
\text { Years } \\
\text { of } \\
\text { School }\end{array}$} \\
\hline & & & No & \multicolumn{2}{|c|}{ Primary } & \multicolumn{2}{|c|}{ Secondary } & \multicolumn{2}{|c|}{ Higher } & \\
\hline & & & School & Total & Full & Total & Full & Total & Full & \\
\hline \multirow{6}{*}{$\begin{array}{l}\text { World } \\
\text { (109) }\end{array}$} & 1960 & 1013 & 34.7 & 43.5 & 21.2 & 18.0 & 7.3 & 3.7 & 2.4 & 4.61 \\
\hline & 1970 & 1197 & 32.7 & 40.7 & 20.7 & 21.3 & 9.2 & 5.3 & 3.5 & 5.08 \\
\hline & 1980 & 1455 & 31.1 & 33.4 & 14.4 & 27.2 & 13.2 & 8.3 & 5.3 & 5.77 \\
\hline & 1990 & 1803 & 27.6 & 31.0 & 13.5 & 29.5 & 13.0 & 11.9 & 7.7 & 6.43 \\
\hline & 1995 & 1905 & 26.7 & 32.2 & 13.7 & 28.0 & 12.6 & 13.0 & 8.3 & 6.49 \\
\hline & 2000 & 2109 & 24.7 & 33.2 & 13.9 & 27.8 & 12.4 & 14.3 & 9.1 & 6.72 \\
\hline \multirow{6}{*}{$\begin{array}{l}\text { All } \\
\text { Developing } \\
\text { (73) }\end{array}$} & 1960 & 469 & 68.0 & 26.2 & 8.3 & 5.1 & 1.9 & 0.8 & 0.5 & 1.79 \\
\hline & 1970 & 585 & 62.1 & 29.3 & 10.5 & 6.9 & 2.8 & 1.7 & 1.2 & 2.30 \\
\hline & 1980 & 752 & 55.7 & 28.0 & 8.6 & 13.0 & 5.3 & 3.2 & 2.2 & 3.08 \\
\hline & 1990 & 1004 & 46.9 & 31.5 & 11.2 & 16.3 & 7.3 & 5.3 & 3.6 & 3.97 \\
\hline & 1995 & 1157 & 41.8 & 33.5 & 11.9 & 18.3 & 8.2 & 6.3 & 4.3 & 4.47 \\
\hline & 2000 & 1327 & 37.2 & 35.9 & 12.8 & 19.7 & 8.8 & 7.2 & 4.9 & 4.89 \\
\hline \multirow{6}{*}{$\begin{array}{l}\text { Middle East/ } \\
\text { North Africa } \\
\text { (11) }\end{array}$} & 1960 & 19 & 82.3 & 12.9 & 5.0 & 3.7 & 1.8 & 1.1 & 0.6 & 1.14 \\
\hline & 1970 & 25 & 78.3 & 13.9 & 5.1 & 5.9 & 3.0 & 1.8 & 1.1 & 1.51 \\
\hline & 1980 & 34 & 67.3 & 18.4 & 6.5 & 10.4 & 5.5 & 3.9 & 2.4 & 2.47 \\
\hline & 1990 & 50 & 51.6 & 25.4 & 8.8 & 17.1 & 9.3 & 5.9 & 3.7 & 3.77 \\
\hline & 1995 & 59 & 43.9 & 28.7 & 9.9 & 20.0 & 10.8 & 7.4 & 4.7 & 4.46 \\
\hline & 2000 & 68 & 37.0 & 31.6 & 10.9 & 22.2 & 12.1 & 9.1 & 5.9 & 5.08 \\
\hline \multirow{6}{*}{$\begin{array}{l}\text { Sub-Saharan } \\
\text { Africa (22) }\end{array}$} & 1960 & 41 & 76.0 & 17.9 & 5.8 & 5.9 & 1.5 & 0.2 & 0.1 & 1.39 \\
\hline & 1970 & 52 & 71.9 & 20.1 & 4.4 & 7.1 & 1.7 & 0.9 & 0.7 & 1.63 \\
\hline & 1980 & 66 & 61.8 & 28.6 & 6.7 & 9.0 & 2.5 & 0.7 & 0.5 & 2.14 \\
\hline & 1990 & 90 & 51.5 & 35.3 & 8.1 & 11.5 & 3.3 & 1.5 & 1.2 & 2.79 \\
\hline & 1995 & 104 & 45.6 & 32.5 & 7.3 & 19.0 & 6.8 & 2.6 & 2.0 & 3.62 \\
\hline & 2000 & 120 & 43.5 & 34.2 & 7.7 & 19.2 & 6.6 & 3.0 & 2.4 & 3.78 \\
\hline \multirow{6}{*}{$\begin{array}{l}\text { Latin Ameri./ } \\
\text { Caribbean } \\
\text { (23) }\end{array}$} & 1960 & 82 & 38.7 & 49.3 & 13.1 & 10.0 & 3.8 & 2.0 & 1.3 & 3.13 \\
\hline & 1970 & 104 & 35.7 & 50.9 & 17.4 & 10.9 & 4.5 & 2.6 & 1.7 & 3.49 \\
\hline & 1980 & 139 & 28.4 & 53.2 & 13.4 & 12.9 & 5.4 & 5.5 & 3.6 & 4.07 \\
\hline & 1990 & 186 & 20.6 & 53.9 & 15.5 & 16.6 & 7.0 & 8.9 & 5.8 & 4.97 \\
\hline & 1995 & 215 & 19.2 & 51.8 & 14.8 & 18.4 & 7.8 & 10.5 & 6.9 & 5.38 \\
\hline & 2000 & 246 & 17.7 & 50.6 & 14.4 & 19.9 & 8.4 & 11.8 & 7.7 & 5.73 \\
\hline
\end{tabular}


Table 3--continued

\begin{tabular}{|c|c|c|c|c|c|c|c|c|c|c|}
\hline \multirow{4}{*}{$\begin{array}{c}\text { Region } \\
\text { (no. of } \\
\text { countries) }\end{array}$} & \multirow{4}{*}{ Year } & \multirow{4}{*}{$\begin{array}{c}\text { Pop. } \\
\text { over } 25 \\
\text { (mill.) }\end{array}$} & \multicolumn{7}{|c|}{$\underline{\text { Highest level attained }}$} & \multirow{4}{*}{$\begin{array}{c}\text { Average } \\
\text { Years } \\
\text { of } \\
\text { School }\end{array}$} \\
\hline & & & No & \multicolumn{2}{|c|}{ Primary } & \multicolumn{2}{|c|}{ Secondary } & \multicolumn{2}{|c|}{ Higher } & \\
\hline & & & School & Total & Full & Total & Full & Total & Full & \\
\hline & & & & & ntage of & the popt & llation ag & & & \\
\hline East Asia/ & 1960 & 79 & 61.3 & 31.4 & 15.0 & 5.7 & 2.3 & 1.6 & 1.1 & 2.26 \\
\hline \multirow[t]{5}{*}{ Pacific (10) } & 1970 & 100 & 43.7 & 43.8 & 17.4 & 9.7 & 4.7 & 2.8 & 1.8 & 3.29 \\
\hline & 1980 & 131 & 30.1 & 49.4 & 17.3 & 15.6 & 8.0 & 4.8 & 3.2 & 4.39 \\
\hline & 1990 & 178 & 33.1 & 35.1 & 18.3 & 24.1 & 13.6 & 7.6 & 5.2 & 5.35 \\
\hline & 1995 & 205 & 27.1 & 36.6 & 18.9 & 26.2 & 15.0 & 10.1 & 6.8 & 6.03 \\
\hline & 2000 & 233 & 22.8 & 37.7 & 19.3 & 27.4 & 15.6 & 12.1 & 8.1 & 6.50 \\
\hline \multirow{6}{*}{$\begin{array}{l}\text { South Asia } \\
\text { (7) }\end{array}$} & 1960 & 248 & 77.3 & 19.3 & 5.2 & 3.3 & 1.3 & 0.1 & 0.1 & 1.31 \\
\hline & 1970 & 304 & 74.2 & 19.8 & 7.4 & 4.6 & 1.8 & 1.2 & 0.9 & 1.75 \\
\hline & 1980 & 382 & 72.4 & 12.2 & 4.3 & 13.1 & 4.9 & 2.3 & 1.6 & 2.48 \\
\hline & 1990 & 499 & 60.3 & 21.8 & 7.8 & 14.2 & 5.6 & 3. & 2.6 & 3.34 \\
\hline & 1995 & 574 & 54.7 & 26.2 & 9.4 & 15.2 & 6.0 & 4.0 & 2.8 & 3.73 \\
\hline & 2000 & 660 & 48.4 & 30.6 & 11.0 & 16.7 & 6.5 & 4.3 & 3.0 & 4.19 \\
\hline \multirow{6}{*}{$\begin{array}{l}\text { Advanced } \\
\text { Countries } \\
\text { (23) }\end{array}$} & 1960 & 362 & 6.5 & 53.6 & 31.5 & 32. & 13.4 & 7. & 4.3 & 6.97 \\
\hline & 1970 & 404 & 5.1 & 50.6 & 32.1 & 34.4 & 15.9 & 9.9 & 5.7 & 7.50 \\
\hline & 1980 & 467 & 5.3 & 35.1 & 17.9 & 43.2 & 24.4 & 16.4 & 9.4 & 8.67 \\
\hline & 1990 & 535 & 4.2 & 31.2 & 15.9 & 40.5 & 19.1 & 24.0 & 13.9 & 9.25 \\
\hline & 1995 & 582 & 4.0 & 28.7 & 14.9 & 41.4 & 19.4 & 25.9 & 15.0 & 9.57 \\
\hline & 2000 & 612 & 4.1 & 27.4 & 14.4 & 39.4 & 18.4 & 29.1 & 16.8 & 9.80 \\
\hline \multirow{6}{*}{$\begin{array}{l}\text { Transitional } \\
\text { economies } \\
\text { (13) }\end{array}$} & 1960 & 182 & 5.3 & 67.9 & 33.7 & 22.9 & 9.3 & 3.9 & 3.4 & 7.17 \\
\hline & 1970 & 207 & 3.7 & 53.4 & 27.3 & 36.5 & 14.4 & 6. & 5.5 & 8.18 \\
\hline & 1980 & 236 & 3.6 & 47.4 & 25.8 & 40.5 & 15.9 & 8.5 & 7.4 & 8.65 \\
\hline & 1990 & 264 & 1.6 & 28.4 & 17.3 & 57.3 & 22.6 & 12.7 & 11.0 & 10.02 \\
\hline & 1995 & 167 & 1.4 & 35.9 & 22.4 & 48.4 & 19.1 & 14.2 & 12.3 & 9.72 \\
\hline & 2000 & 170 & 1.5 & 33.0 & 20.5 & 49.1 & 19.3 & 16.4 & 14.1 & 9.95 \\
\hline
\end{tabular}

Notes: Regional averages are weighted by each country's population. See Appendix Tables for the list of countries included in each region/group. Former Germany, East is classified as Transitional economies group until 1990 and since then belongs to Advanced countries group as the united Germany. Former Soviet Union countries except Russian Republic are excluded since 1995. The group of transitional economies includes Croatia, Czech Republic, Slovakia, and Slovenia since 1995. "Total" refers to the percentage of the population for whom the indicated level is the highest attained. "Full" refers to those who had the completion of the indicated level as the highest attained. 


\section{Table 4}

Trends of Educational Attainment of the Total Population Aged 15 and Over by Region

\begin{tabular}{|c|c|c|c|c|c|c|c|c|c|c|}
\hline \multirow{3}{*}{$\begin{array}{l}\text { Region } \\
\text { (no. of } \\
\text { countries) }\end{array}$} & \multirow{3}{*}{ Year } & \multirow{3}{*}{$\begin{array}{l}\text { Pop. } \\
\text { over } 15 \\
\text { (mill.) }\end{array}$} & \multicolumn{7}{|c|}{$\underline{\text { Highest level attained }}$} & \multirow{3}{*}{$\begin{array}{l}\text { Average } \\
\text { Years } \\
\text { of } \\
\text { School }\end{array}$} \\
\hline & & & No & \multicolumn{2}{|c|}{ Primary } & \multicolumn{2}{|c|}{ Secondary } & \multicolumn{2}{|c|}{ Higher } & \\
\hline & & & School & $\begin{array}{l}\text { Total } \\
\text { (Percenta }\end{array}$ & $\begin{array}{l}\text { Full } \\
\text { ge of the }\end{array}$ & $\begin{array}{l}\text { Total } \\
\text { populat }\end{array}$ & $\begin{array}{l}\text { Full } \\
\text { on aged }\end{array}$ & $\begin{array}{l}\text { Total } \\
15 \text { and o }\end{array}$ & $\begin{array}{l}\text { Full } \\
\text { ver) }\end{array}$ & \\
\hline \multirow{6}{*}{$\begin{array}{l}\text { World } \\
\text { (109) }\end{array}$} & 1960 & 1379 & 34.6 & 41.7 & 19.8 & 20.3 & 7.1 & 3.3 & 1.6 & 4.64 \\
\hline & 1970 & 1660 & 31.4 & 39.6 & 19.9 & 24.0 & 7.8 & 5.0 & 2.2 & 5.16 \\
\hline & 1980 & 2042 & 29.5 & 31.5 & 13.1 & 31.6 & 12.2 & 7.5 & 3.4 & 5.92 \\
\hline & 1990 & 2480 & 26.4 & 29.8 & 12.3 & 33.5 & 11.9 & 10.3 & 5.1 & 6.43 \\
\hline & 1995 & 2596 & 26.1 & 31.0 & 12.8 & 31.6 & 11.3 & 11.3 & 5.4 & 6.44 \\
\hline & 2000 & 2846 & 24.2 & 31.9 & 12.9 & 31.4 & 11.1 & 12.6 & 6.0 & 6.66 \\
\hline \multirow{6}{*}{$\begin{array}{l}\text { All } \\
\text { Developing } \\
\text { (73) }\end{array}$} & 1960 & 685 & 64.1 & 28.8 & 10.0 & 6.3 & 1.7 & 0.8 & 0.4 & 2.05 \\
\hline & 1970 & 866 & 56.1 & 33.0 & 12.1 & 9.2 & 2.5 & 1.7 & 0.6 & 2.67 \\
\hline & 1980 & 1138 & 49.7 & 29.5 & 9.3 & 17.6 & 5.8 & 3.1 & 1.2 & 3.57 \\
\hline & 1990 & 1488 & 41.7 & 31.6 & 10.6 & 22.0 & 7.5 & 4.6 & 2.2 & 4.42 \\
\hline & 1995 & 1684 & 38.3 & 32.5 & 11.2 & 23.5 & 8.0 & 5.7 & 2.6 & 4.79 \\
\hline & 2000 & 1905 & 34.4 & 34.5 & 11.9 & 24.6 & 8.3 & 6.5 & 3.0 & 5.13 \\
\hline \multirow{6}{*}{$\begin{array}{l}\text { Middle East/ } \\
\text { North Africa } \\
\text { (11) }\end{array}$} & 1960 & 28 & 81.0 & 12.9 & 5.2 & 5.2 & 1.6 & 0.9 & 0.4 & 1.23 \\
\hline & 1970 & 37 & 69.8 & 18.0 & 6.6 & 10.5 & 3.2 & 1.7 & 0.6 & 2.07 \\
\hline & 1980 & 52 & 55.5 & 23.1 & 8.1 & 17.8 & 5.8 & 3.6 & 1.4 & 3.29 \\
\hline & 1990 & 76 & 42.8 & 27.8 & 9.6 & 23.7 & 8.2 & 5.6 & 2.3 & 4.38 \\
\hline & 1995 & 89 & 36.0 & 29.9 & 10.3 & 27.0 & 9.3 & 7.2 & 2.8 & 4.98 \\
\hline & 2000 & 103 & 32.0 & 29.6 & 10.2 & 29.5 & 10.2 & 8.8 & 3.4 & 5.44 \\
\hline \multirow{6}{*}{$\begin{array}{l}\text { Sub-Saharan } \\
\text { Africa (22) }\end{array}$} & 1960 & 66 & 68.9 & 24.4 & 7.0 & 6.4 & 1.5 & 0.2 & 0.2 & 1.74 \\
\hline & 1970 & 85 & 63.8 & 26.9 & 6.2 & 8.5 & 1.8 & 0.8 & 0.5 & 2.07 \\
\hline & 1980 & 112 & 56.8 & 32.5 & 7.4 & 10.0 & 1.4 & 0.6 & 0.3 & 2.39 \\
\hline & 1990 & 151 & 45.9 & 38.1 & 8.5 & 14.6 & 1.9 & 1.3 & 0.6 & 3.14 \\
\hline & 1995 & 176 & 44.5 & 37.4 & 8.2 & 16.0 & 2.4 & 2.1 & 0.9 & 3.39 \\
\hline & 2000 & 204 & 42.8 & 38.1 & 8.3 & 17.0 & 2.5 & 2.2 & 0.9 & 3.52 \\
\hline \multirow{6}{*}{$\begin{array}{l}\text { Latin Ameri./ } \\
\text { Caribbean } \\
\text { (23) }\end{array}$} & 1960 & 119 & 37.9 & 47.7 & 12.8 & 12.6 & 4.1 & 1.8 & 0.9 & 3.30 \\
\hline & 1970 & 156 & 31.2 & 52.1 & 18.4 & 14.3 & 5.0 & 2.5 & 1.0 & 3.82 \\
\hline & 1980 & 210 & 23.8 & 52.9 & 13.7 & 18.1 & 5.6 & 5.2 & 2.0 & 4.43 \\
\hline & 1990 & 270 & 17.2 & 53.1 & 13.2 & 21.4 & 7.4 & 8.2 & 3.7 & 5.32 \\
\hline & 1995 & 306 & 15.8 & 50.9 & 14.2 & 23.7 & 8.2 & 9.5 & 4.2 & 5.74 \\
\hline & 2000 & 343 & 14.6 & 49.6 & 13.8 & 24.9 & 8.6 & 10.9 & 4.9 & 6.06 \\
\hline
\end{tabular}


Table 4--continued

\begin{tabular}{|c|c|c|c|c|c|c|c|c|c|c|}
\hline \multirow{3}{*}{$\begin{array}{l}\text { Region } \\
\text { (no. of } \\
\text { countries) }\end{array}$} & \multirow{3}{*}{ Year } & \multirow{3}{*}{$\begin{array}{l}\text { Pop. } \\
\text { over 15 } \\
\text { (mill.) }\end{array}$} & \multicolumn{7}{|c|}{$\underline{\text { Highest level attained }}$} & \multirow{3}{*}{$\begin{array}{c}\text { Average } \\
\text { Years } \\
\text { of } \\
\text { School }\end{array}$} \\
\hline & & & No & \multicolumn{2}{|c|}{ Primary } & \multicolumn{2}{|c|}{ Secondary } & \multicolumn{2}{|c|}{ Higher } & \\
\hline & & & School & Total & Full & Total & Full & Total & Full & \\
\hline East Asia/ & 1960 & 116 & 52.5 & 37.4 & 19.4 & 8.5 & 2.8 & 1.6 & 0.8 & 2.83 \\
\hline Pacific & 1970 & 148 & 35.4 & 48.9 & 20.0 & 13.0 & 4.1 & 2.7 & 1.2 & 3.80 \\
\hline & 1980 & 198 & 22.6 & 50.4 & 18.9 & 21.9 & 10.1 & 5.0 & 2.2 & 5.10 \\
\hline & 1990 & 259 & 26.4 & 36.1 & 18.3 & 30.0 & 13.1 & 7.4 & 3.4 & 5.84 \\
\hline & 1995 & 289 & 22.5 & 36.0 & 17.9 & 31.4 & 14.5 & 10.0 & 4.4 & 6.35 \\
\hline & 2000 & 320 & 19.8 & 35.8 & 18.1 & 32.7 & 14.8 & 11.7 & 5.0 & 6.71 \\
\hline South Asia & 1960 & 355 & 74.3 & 21.8 & 7.0 & 3.5 & 0.5 & 0.4 & 0.1 & 1.51 \\
\hline & 1970 & 440 & 69.3 & 23.4 & 8.8 & 6.1 & 1.1 & 1.2 & 0.3 & 2.05 \\
\hline & 1980 & 566 & 66.9 & 13.6 & 4.8 & 17.5 & 5.2 & 2.1 & 0.7 & 2.97 \\
\hline & 1990 & 730 & 55.2 & 21.0 & 7.5 & 20.8 & 6.5 & 2. & 1.6 & 3.85 \\
\hline & 1995 & 824 & 51.2 & 23.7 & 8.4 & 21.8 & 6.8 & 3.3 & 1.8 & 4.16 \\
\hline & 2000 & 934 & 45.2 & 28.2 & 10.0 & 22.9 & 7.0 & 3.7 & 2.0 & 4.57 \\
\hline Advanced & 1960 & 458 & 6.1 & 50.8 & 29.8 & 36.4 & 13.5 & 6.7 & 3.0 & 7.06 \\
\hline Countries & 1970 & 524 & 5.1 & 46.7 & 30.1 & 38.3 & 13.3 & 9.9 & 4.1 & 7.56 \\
\hline (23) & 1980 & 598 & 4.8 & 30.8 & 15.8 & 48.7 & 24.9 & 15.8 & 6.9 & 8.86 \\
\hline & 1990 & 664 & 4.5 & 28.1 & 14.3 & 45.0 & 17.4 & 22.4 & 10.4 & 9.19 \\
\hline & 1995 & 707 & 3.8 & 26.4 & 13.9 & 45.0 & 17.4 & 24.8 & 11.5 & 9.52 \\
\hline & 2000 & 732 & 3.7 & 25.1 & 13.4 & 43.1 & 16.6 & 28.1 & 13.0 & 9.76 \\
\hline Transitional & 1960 & 236 & 4.5 & 61.6 & 28.8 & 30.0 & 10.3 & 3.8 & 2.2 & 7.42 \\
\hline economies & 1970 & 270 & 3.1 & 47.1 & 24.9 & 43.5 & 14.1 & 6.3 & 3.5 & 8.47 \\
\hline & 1980 & 307 & 2.8 & 40.0 & 21.9 & 50.1 & 11.5 & 7.7 & 4.5 & 8.90 \\
\hline & 1990 & 328 & 1.7 & 25.4 & 15.6 & 61.7 & 20.9 & 11.2 & 7.7 & 9.97 \\
\hline & 1995 & 205 & 2.1 & 35.1 & 22.0 & 51.4 & 17.3 & 11.4 & 7.7 & 9.45 \\
\hline & 2000 & 210 & 2.2 & 32.4 & 20.2 & 51.6 & 17.4 & 13.9 & 9.4 & 9.68 \\
\hline
\end{tabular}

Note: See table 3. 
Table 5

Educational Attainment by Sex

\begin{tabular}{|c|c|c|c|c|c|c|c|}
\hline \multirow{2}{*}{$\begin{array}{l}\text { Region } \\
\text { (no. of } \\
\text { countries) }\end{array}$} & \multirow[t]{2}{*}{ Year } & \multicolumn{3}{|c|}{ Population Age 25 and Over } & \multicolumn{3}{|c|}{ Population Age 15 and Over } \\
\hline & & $\begin{array}{l}\text { Females } \\
\text { (A) }\end{array}$ & $\begin{array}{l}\text { Males } \\
\text { (B) }\end{array}$ & $\begin{array}{c}\text { Gender ratio } \\
\text { (A/B, } \%)\end{array}$ & $\begin{array}{l}\text { Females } \\
\text { (A) }\end{array}$ & $\begin{array}{l}\text { Males } \\
\text { (B) }\end{array}$ & $\begin{array}{c}\text { Gender ratio } \\
(\mathrm{A} / \mathrm{B}, \%)\end{array}$ \\
\hline $\begin{array}{l}\text { World } \\
\text { (109) }\end{array}$ & $\begin{array}{l}1960 \\
1970 \\
1980 \\
1990 \\
1995 \\
2000\end{array}$ & $\begin{array}{l}4.28 \\
4.65 \\
5.27 \\
5.84 \\
5.94 \\
6.18\end{array}$ & $\begin{array}{l}4.96 \\
5.54 \\
6.31 \\
7.03 \\
7.05 \\
7.28\end{array}$ & $\begin{array}{l}86.4 \\
83.9 \\
83.6 \\
83.1 \\
84.3 \\
84.9\end{array}$ & $\begin{array}{l}4.31 \\
4.74 \\
5.42 \\
5.93 \\
5.94 \\
6.13\end{array}$ & $\begin{array}{l}4.98 \\
5.59 \\
6.43 \\
6.94 \\
6.95 \\
7.19\end{array}$ & $\begin{array}{l}86.7 \\
84.7 \\
84.3 \\
85.5 \\
85.4 \\
85.3\end{array}$ \\
\hline $\begin{array}{l}\text { All } \\
\text { Developing } \\
\text { (73) }\end{array}$ & $\begin{array}{l}1960 \\
1970 \\
1980 \\
1990 \\
1995 \\
2000\end{array}$ & $\begin{array}{l}1.16 \\
1.52 \\
2.20 \\
3.07 \\
3.60 \\
4.03\end{array}$ & $\begin{array}{l}2.39 \\
3.07 \\
3.94 \\
4.86 \\
5.34 \\
5.74\end{array}$ & $\begin{array}{l}48.5 \\
49.7 \\
55.9 \\
63.1 \\
67.4 \\
70.2\end{array}$ & $\begin{array}{l}1.46 \\
1.94 \\
2.74 \\
3.61 \\
3.99 \\
4.33\end{array}$ & $\begin{array}{l}2.63 \\
3.38 \\
4.37 \\
5.21 \\
5.56 \\
5.92\end{array}$ & $\begin{array}{l}55.7 \\
57.2 \\
62.5 \\
69.3 \\
71.8 \\
73.2\end{array}$ \\
\hline $\begin{array}{l}\text { Middle East/ } \\
\text { North Africa } \\
\text { (11) }\end{array}$ & $\begin{array}{l}1960 \\
1970 \\
1980 \\
1990 \\
1995 \\
2000\end{array}$ & $\begin{array}{l}0.77 \\
0.93 \\
1.64 \\
2.73 \\
3.45 \\
4.09\end{array}$ & $\begin{array}{l}1.51 \\
2.11 \\
3.31 \\
4.80 \\
5.47 \\
6.06\end{array}$ & $\begin{array}{l}51.3 \\
43.9 \\
49.7 \\
56.9 \\
63.1 \\
67.5\end{array}$ & $\begin{array}{l}0.83 \\
1.39 \\
2.41 \\
3.57 \\
4.21 \\
4.69\end{array}$ & $\begin{array}{l}1.63 \\
2.75 \\
4.15 \\
5.17 \\
5.74 \\
6.17\end{array}$ & $\begin{array}{l}51.0 \\
50.5 \\
58.0 \\
69.1 \\
73.3 \\
76.0\end{array}$ \\
\hline $\begin{array}{l}\text { Sub-Saharan } \\
\text { Africa (22) }\end{array}$ & $\begin{array}{l}1960 \\
1970 \\
1980 \\
1990 \\
1995 \\
2000\end{array}$ & $\begin{array}{l}1.04 \\
1.17 \\
1.52 \\
2.16 \\
2.92 \\
3.14\end{array}$ & $\begin{array}{l}1.76 \\
2.12 \\
2.81 \\
3.45 \\
4.36 \\
4.45\end{array}$ & $\begin{array}{l}59.3 \\
55.4 \\
54.0 \\
62.6 \\
66.9 \\
70.5\end{array}$ & $\begin{array}{l}1.34 \\
1.56 \\
1.91 \\
2.49 \\
2.82 \\
3.01\end{array}$ & $\begin{array}{l}2.17 \\
2.60 \\
2.89 \\
3.83 \\
3.98 \\
4.04\end{array}$ & $\begin{array}{l}61.8 \\
60.1 \\
66.0 \\
65.0 \\
70.8 \\
74.4\end{array}$ \\
\hline $\begin{array}{l}\text { Latin Ameri./ } \\
\text { Caribbean } \\
(23)\end{array}$ & $\begin{array}{l}1960 \\
1970 \\
1980 \\
1990 \\
1995 \\
2000\end{array}$ & $\begin{array}{l}2.84 \\
3.08 \\
3.84 \\
4.81 \\
5.25 \\
5.61\end{array}$ & $\begin{array}{l}3.43 \\
3.90 \\
4.30 \\
5.13 \\
5.52 \\
5.86\end{array}$ & $\begin{array}{l}82.9 \\
78.9 \\
89.5 \\
93.6 \\
95.1 \\
95.7\end{array}$ & $\begin{array}{l}3.24 \\
3.52 \\
4.29 \\
5.24 \\
5.58 \\
5.81\end{array}$ & $\begin{array}{l}3.36 \\
4.14 \\
4.57 \\
5.41 \\
5.91 \\
6.31\end{array}$ & $\begin{array}{l}96.3 \\
85.0 \\
93.7 \\
96.8 \\
94.4 \\
92.2\end{array}$ \\
\hline
\end{tabular}


Table 5--continued

\begin{tabular}{|c|c|c|c|c|c|c|c|}
\hline \multirow{2}{*}{$\begin{array}{c}\text { Region } \\
\text { (no. of } \\
\text { Countries) }\end{array}$} & \multirow[t]{2}{*}{ Year } & \multicolumn{3}{|c|}{ Population Age 25 and Over } & \multicolumn{3}{|c|}{ Population Age 15 and Over } \\
\hline & & $\begin{array}{c}\text { Females } \\
\text { (A) }\end{array}$ & $\begin{array}{l}\text { Males } \\
\text { (B) }\end{array}$ & $\begin{array}{l}\text { Gender ratio } \\
(\mathrm{A} / \mathrm{B}, \%)\end{array}$ & $\begin{array}{l}\text { Females } \\
\text { (A) }\end{array}$ & $\begin{array}{l}\text { Males } \\
\text { (B) }\end{array}$ & $\begin{array}{c}\text { Gender ratio } \\
(\mathrm{A} / \mathrm{B}, \%)\end{array}$ \\
\hline East Asia/ & 1960 & 1.49 & 3.04 & 49.0 & 2.10 & 3.58 & 58.8 \\
\hline Pacific (10) & 1970 & 2.40 & 4.19 & 57.2 & 3.06 & 4.54 & 67.5 \\
\hline & 1980 & 3.55 & 5.23 & 67.9 & 4.41 & 5.80 & 76.1 \\
\hline & 1990 & 4.63 & 6.09 & 76.1 & 5.33 & 6.36 & 83.7 \\
\hline & 1995 & 5.38 & 6.70 & 80.3 & 5.85 & 6.84 & 85.6 \\
\hline & 2000 & 5.92 & 7.09 & 83.5 & 6.20 & 7.23 & 85.8 \\
\hline South Asia & 1960 & 0.52 & 2.04 & 25.3 & 0.71 & 2.25 & 31.4 \\
\hline & 1970 & 0.78 & 2.67 & 29.2 & 1.08 & 2.95 & 36.8 \\
\hline & 1980 & 1.27 & 3.63 & 35.0 & 1.73 & 4.12 & 41.9 \\
\hline & 1990 & 2.02 & 4.59 & 44.0 & 2.60 & 5.02 & 51.9 \\
\hline & 1995 & 2.43 & 4.96 & 49.0 & 2.94 & 5.31 & 55.4 \\
\hline & 2000 & 2.89 & 5.44 & 53.1 & 3.36 & 5.71 & 58.8 \\
\hline Advanced & 1960 & 6.74 & 7.23 & 93.3 & 6.87 & 7.26 & 94.7 \\
\hline Countries & 1970 & 7.22 & 7.82 & 92.3 & 7.33 & 7.81 & 93.9 \\
\hline (23) & 1980 & 8.39 & 8.98 & 93.5 & 8.65 & 9.09 & 95.2 \\
\hline & 1990 & 8.85 & 9.69 & 91.3 & 9.01 & 9.38 & 96.1 \\
\hline & 1995 & 9.28 & 9.90 & 93.7 & 9.29 & 9.77 & 95.0 \\
\hline & 2000 & 9.55 & 10.06 & 94.9 & 9.53 & 10.01 & 95.3 \\
\hline Transitional & 1960 & 6.70 & 7.80 & 85.9 & 7.01 & 7.95 & 88.2 \\
\hline economies & 1970 & 7.74 & 8.74 & 88.6 & 8.09 & 8.93 & 90.6 \\
\hline (13) & 1980 & 8.21 & 9.20 & 89.2 & 8.50 & 9.36 & 90.7 \\
\hline & 1990 & 9.65 & 10.47 & 92.2 & 9.69 & 10.30 & 94.0 \\
\hline & 1995 & 9.76 & 9.67 & 100.9 & 9.67 & 9.20 & 105.1 \\
\hline & 2000 & 10.01 & 9.87 & 101.5 & 9.89 & 9.44 & 104.7 \\
\hline
\end{tabular}

Note: The "World" does not include former Soviet Union countries except Russia since 1995. See Notes to Table 3. 


\section{Table 6. International Test by Students (TIMMS) and Adults (IALS), 1994-95 Mean Scores and Rank}

\begin{tabular}{|c|c|c|c|c|c|c|c|c|c|c|}
\hline \multirow{3}{*}{$\begin{array}{l}\text { Country } \\
\text { Australia }\end{array}$} & \multicolumn{4}{|c|}{ Scores of 7th Grade(TIMMS) } & \multicolumn{6}{|c|}{$\underline{\text { Scores of Adult Literacy Test (IALS) }}$} \\
\hline & \multicolumn{2}{|c|}{ Math. } & \multicolumn{2}{|c|}{ Science } & \multicolumn{2}{|c|}{ Prose } & \multicolumn{2}{|c|}{ Document } & \multicolumn{2}{|c|}{ Quantitative } \\
\hline & 498 & 15 & 504 & 12 & 274.2 & 6 & 273.3 & 7 & 275.9 & 7 \\
\hline Austria & 509 & 8 & 519 & 7 & & & & & & \\
\hline Belgium (French) & 507 & 10 & 442 & 29 & 271.8 & 8 & 278.2 & 5 & 282.0 & 4 \\
\hline Bulgaria & 514 & 7 & 531 & 5 & & & & & & \\
\hline Canada & 494 & 18 & 499 & 13 & 278.8 & 3 & 279.3 & 4 & 281.0 & 5 \\
\hline Colombia & 369 & 36 & 387 & 36 & & & & & & \\
\hline Cyprus & 446 & 31 & 420 & 34 & & & & & & \\
\hline Czech Republic & 523 & 5 & 533 & 3 & & & & & & \\
\hline Denmark & 465 & 25 & 439 & 30 & & & & & & \\
\hline France & 492 & 19 & 451 & 27 & & & & & & \\
\hline Germany & 484 & 20 & 499 & 14 & 275.9 & 4 & 285.1 & 3 & 293.3 & 2 \\
\hline Greece & 440 & 32 & 449 & 28 & & & & & & \\
\hline Hong Kong & 564 & 4 & 495 & 15 & & & & & & \\
\hline Hungary & 502 & 12 & 518 & 8 & & & & & & \\
\hline Iceland & 459 & 28 & 462 & 25 & & & & & & \\
\hline Iran, I.R. of & 401 & 35 & 436 & 31 & & & & & & \\
\hline Ireland & 500 & 14 & 495 & 16 & 265.7 & 10 & 259.3 & 11 & 264.6 & 11 \\
\hline Japan & 571 & 3 & 531 & 4 & & & & & & \\
\hline Korea & 577 & 2 & 535 & 2 & & & & & & \\
\hline Latvia & 462 & 26 & 435 & 32 & & & & & & \\
\hline Lithuania & 428 & 33 & 403 & 35 & & & & & & \\
\hline Netherlands & 516 & 6 & 517 & 9 & 282.7 & 2 & 286.9 & 2 & 287.7 & 3 \\
\hline New Zealand & 472 & 23 & 481 & 23 & 275.2 & 5 & 269.1 & 8 & 270.7 & 9 \\
\hline Norway & 461 & 27 & 483 & 22 & & & & & & \\
\hline Poland & & & & & 229.5 & 12 & 223.9 & 12 & 234.9 & 12 \\
\hline Portugal & 423 & 34 & 428 & 33 & & & & & & \\
\hline Romania & 454 & 29 & 452 & 26 & & & & & & \\
\hline Russian & 501 & 13 & 484 & 21 & & & & & & \\
\hline Federation & & & & & & & & & & \\
\hline Singapore & 601 & 1 & 545 & 1 & & & & & & \\
\hline Slovak Republic & 508 & 9 & 510 & 10 & & & & & & \\
\hline Slovenia & 498 & 16 & 530 & 6 & & & & & & \\
\hline South Africa & 348 & 37 & 317 & 37 & & & & & & \\
\hline Spain & 448 & 30 & 477 & 24 & & & & & & \\
\hline Sweden & 477 & 21 & 488 & 19 & 301.3 & 1 & 305.6 & 1 & 305.9 & 1 \\
\hline Switzerland & 506 & 11 & 484 & 20 & 264.8 & 11 & 274.1 & 6 & 280.1 & 6 \\
\hline Thailand & 495 & 17 & 493 & 17 & & & & & & \\
\hline U. K. & 470 & 24 & 490 & 18 & 266.7 & 9 & 267.5 & 10 & 267.2 & 10 \\
\hline United States & 476 & 22 & 508 & 11 & 273.7 & 7 & 267.9 & 9 & 275.2 & 8 \\
\hline
\end{tabular}




\section{Table 6. continued,}

Notes: The TIMMS scores are expressed on proficiency scales (scales ranging from 0 to 1000 , with a mean of 500 and a standard deviation of 100). The IALS test scores are evaluated on a scale of 0 to 500 in each of three domains. For the TIMMS score, Belgium is French-speaking region, and for the IALS score, Belgium is Belgium (Flanders), and Switzerland is French-speaking region. Italics indicate the rank of the country among the participating countries.

Source: IEA, Third International Mathematics and Science Study, 1994-1995, and OECD and Human Resources Development Canada (1998), Literacy Skills for the Knowledge Society: Further Results from the International Adult Literacy Survey, Paris and Ottawa. 
Table 7

Barro-Lee and OECD Estimates of Educational Attainment in 1995

\begin{tabular}{|c|c|c|c|c|c|c|c|c|c|}
\hline \multirow{3}{*}{ Country } & \multicolumn{6}{|c|}{ Barro-Lee Estimates } & \multicolumn{3}{|c|}{ OECD Estimates } \\
\hline & No & Primary & Secondary & & Tertiary & Average & Below & Upper & Tertia \\
\hline & School & Total & Partial & Full & Total & $\begin{array}{l}\text { Years } \\
\text { of school }\end{array}$ & $\begin{array}{c}\text { upper } \\
\text { secondar }\end{array}$ & $\begin{array}{l}\text { secondary } \\
\text { ry }\end{array}$ & \\
\hline \multicolumn{10}{|l|}{ OECD } \\
\hline Australia & 2 & 25 & 28 & 21 & 24 & 10.3 & 47 & 29 & 24 \\
\hline Austria & 1 & 32 & 25 & 31 & 12 & 8.4 & 31 & 62 & 8 \\
\hline Belgium & 5 & 49 & 20 & 10 & 16 & 8.6 & 47 & 29 & 25 \\
\hline Canada & 2 & 20 & 16 & 13 & 49 & 11.2 & 25 & 28 & 47 \\
\hline Czech & 1 & 35 & 33 & 22 & 9 & 9.3 & 17 & 73 & 11 \\
\hline Denmark & 0 & 34 & 8 & 39 & 19 & 9.9 & 38 & 42 & 20 \\
\hline Finland & 0 & 31 & 14 & 35 & 19 & 9.8 & 35 & 45 & 21 \\
\hline France & 1 & 48 & 15 & 22 & 15 & 7.9 & 32 & 50 & 19 \\
\hline Germany & 4 & 28 & 31 & 23 & 15 & 9.6 & 16 & 61 & 23 \\
\hline Greece & 6 & 52 & 7 & 24 & 11 & 8.1 & 57 & 25 & 17 \\
\hline Iceland & 2 & 48 & 21 & 16 & 13 & 8.4 & -- & -- & -- \\
\hline Ireland & 3 & 35 & 26 & 20 & 16 & 8.8 & 53 & 27 & 20 \\
\hline Italy & 14 & 43 & 21 & 12 & 12 & 6.6 & 65 & 27 & 8 \\
\hline Japan & 0 & 31 & 30 & 17 & 22 & 9.4 & -- & -- & -- \\
\hline Luxemberg & -- & -- & -- & -- & -- & -- & 71 & 18 & 11 \\
\hline Korea & 9 & 18 & 16 & 36 & 21 & 10.1 & 40 & 42 & 18 \\
\hline Netherlands & 3 & 32 & 32 & 14 & 19 & 9.0 & 39 & 39 & 22 \\
\hline New Zealand & 0 & 34 & 18 & 9 & 39 & 11.3 & 41 & 34 & 25 \\
\hline Norway & 1 & 12 & 22 & 44 & 21 & 11.8 & 19 & 53 & 29 \\
\hline Portugal & 14 & 61 & 8 & 6 & 10 & 4.5 & 80 & 9 & 11 \\
\hline Spain & 4 & 56 & 16 & 13 & 12 & 6.6 & 72 & 12 & 16 \\
\hline Sweden & 2 & 18 & 15 & 44 & 21 & 11.2 & 25 & 46 & 28 \\
\hline Switzerland & 5 & 26 & 24 & 31 & 15 & 10.2 & 18 & 61 & 21 \\
\hline Turkey & 31 & 47 & 9 & 7 & 7 & 4.6 & 77 & 15 & 8 \\
\hline U. K. & 3 & 41 & 27 & 13 & 16 & 9.0 & 24 & 54 & 21 \\
\hline United States & 1 & 8 & 20 & 24 & 47 & 12.2 & 14 & 53 & 33 \\
\hline \multicolumn{10}{|l|}{ Non-OECD } \\
\hline$\overline{\text { Argentina }}$ & 6 & 53 & 15 & 10 & 16 & 8.1 & 73 & 18 & 9 \\
\hline Brazil & 22 & 59 & 7 & 5 & 8 & 4.3 & 75 & 16 & 9 \\
\hline India & 52 & 28 & 10 & 6 & 5 & 4.2 & 92 & 3 & 6 \\
\hline Indonesia & 44 & 33 & 9 & 10 & 4 & 4.0 & 81 & 15 & 4 \\
\hline Malaysia & 17 & 34 & 19 & 24 & 7 & 7.7 & 67 & 26 & 7 \\
\hline Paraguay & 10 & 64 & 9 & 10 & 8 & 5.7 & 67 & 19 & 14 \\
\hline Thailand & 20 & 62 & 5 & 4 & 9 & 5.7 & 87 & 3 & 11 \\
\hline Uruguay & 3 & 54 & 23 & 9 & 10 & 6.9 & 73 & 12 & 14 \\
\hline
\end{tabular}

Note: The table shows the percentages of the population for whom the indicated level is the highest attained. Barro-Lee data refer to the population aged 25 and above, and the OECD data are for the population of age between 25 and 64. The OECD data on the distribution of education attainment come from OECD, Education at a Glance- OECD Indicators, 1997, 1998. 
Figure 1. Mean Scores of TIMMS and IALS Quantitative Tests in OECD

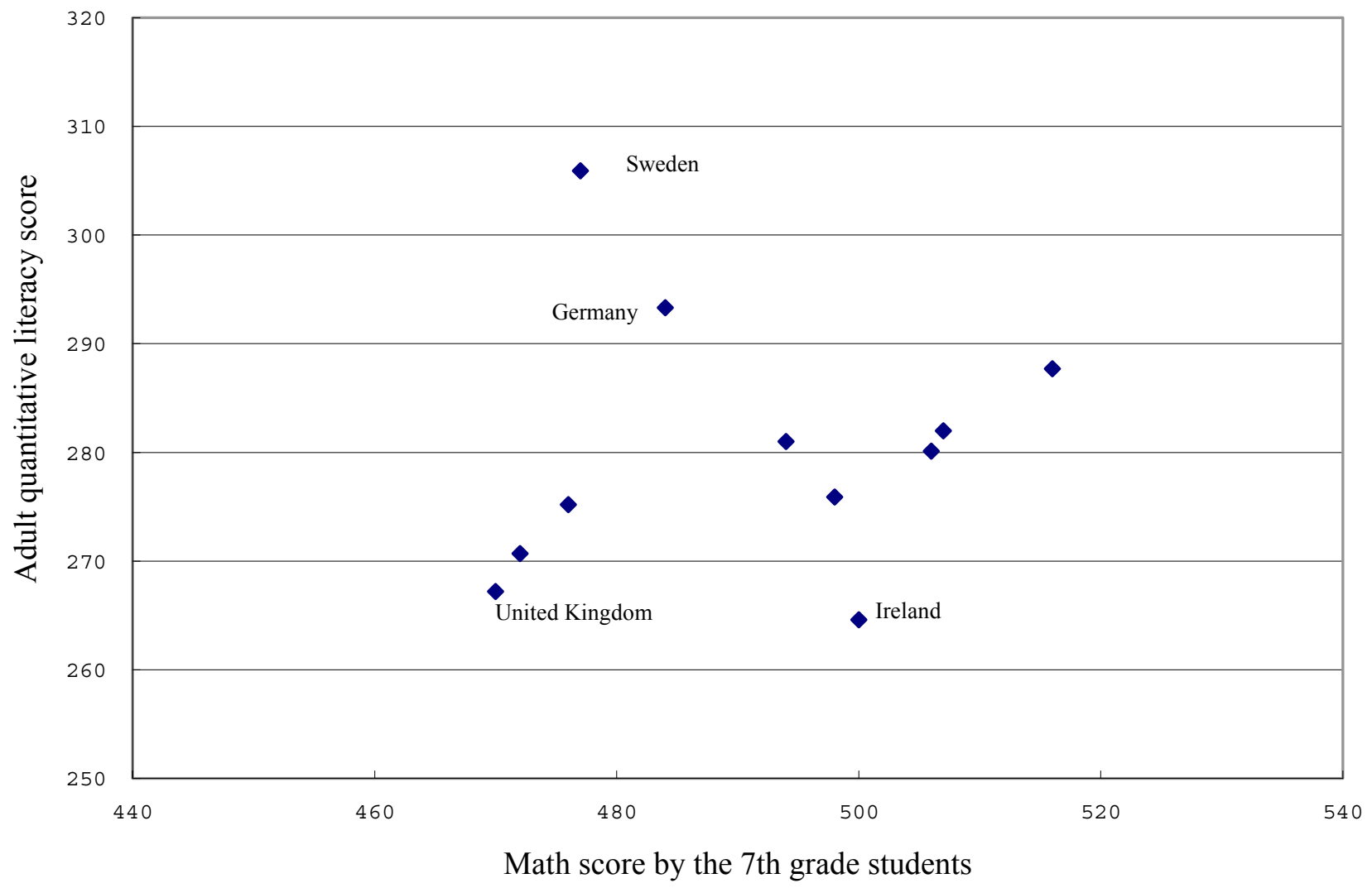

